\title{
Guidelines
}

HORMONE

RESEARCH IN

Horm Res Paediatr 2019;91:223-240

PAEDIATRICS

DOI: $10.1159 / 000499915$

Received: February 24, 2019

Accepted: March 25, 2019

Published online: June 13, 2019

\section{Towards a Rational and Efficient Diagnostic Approach in Children Referred for Growth Failure to the General Paediatrician}

\author{
Jan M. Wit ${ }^{a}$ Gerdine A. Kamp ${ }^{b}$ Wilma Oostdijk ${ }^{a}$ on behalf of the Dutch \\ Working Group on Triage and Diagnosis of Growth Disorders in Children \\ ${ }^{\mathrm{a}}$ Department of Paediatrics, Leiden University Medical Center, Leiden, The Netherlands; ${ }^{\mathrm{b}}$ Department of Paediatrics, \\ Tergooi Hospital, Blaricum, The Netherlands
}

\section{Keywords}

Short stature - Growth disorders - Turner syndrome · SHOX . $\mathrm{NPR} 2 \cdot \mathrm{IHH} \cdot \mathrm{ACAN} \cdot$ Microarray

\begin{abstract}
Based on a recent Dutch national guideline, we propose a structured stepwise diagnostic approach for children with growth failure (short stature and/or growth faltering), aiming at high sensitivity for pathologic causes at acceptable specificity. The first step is a detailed clinical assessment, aiming at obtaining relevant clinical clues from the medical history (including family history), physical examination (emphasising head circumference, body proportions and dysmorphic features) and assessment of the growth curve. The second step consists of screening: a radiograph of the hand and wrist (for bone age and assessment of anatomical abnormalities suggestive for a skeletal dysplasia) and laboratory tests aiming at detecting disorders that can present as isolated short stature (anaemia, growth hormone deficiency, hypothyroidism, coeliac disease, renal failure, metabolic bone diseases, renal tubular acidosis, inflammatory bowel disease, Turner syndrome [TS]). We advise molecular array
\end{abstract}

analysis rather than conventional karyotyping for short girls because this detects not only TS but also copy number variants and uniparental isodisomy, increasing diagnostic yield at a lower cost. Third, in case of diagnostic clues for primary growth disorders, further specific testing for candidate genes or a hypothesis-free approach is indicated; suspicion of a secondary growth disorder warrants adequate further targeted testing.

(C) 2019 The Author(s) Published by S. Karger AG, Basel

\section{Introduction}

The diagnosis of children who are referred to a general paediatrician or paediatric endocrinologist for short stature and/or growth faltering (from now on termed growth failure $[\mathrm{GF}]$ ) is difficult for multiple reasons. First, the many different causes of GF complicate the process of screening for pathologic conditions. Second, for most conditions little information is available about incidence and prevalence. Third, the phenotypic spectrum of each condition is insufficiently known, as is the percentage of cases that can present with isolated GF. Fourth, for each 
condition, little information is available about the distribution of height SD score (HSDS); anecdotal information suggests considerable overlap with the population reference range. Fifth, the multitude of syndromes associated with GF makes it virtually impossible for the clinician to remember their phenotypes. Sixth, in the last 2 decades, several novel genetic causes have been discovered with a relatively high prevalence: up to $13 \%$ for copy number variants (CNVs) [1] and 1-2\% for heterozygous defects of the Short Stature Homeobox gene (SHOX) [2], Natriuretic Peptide Receptor 2 gene (NPR2) [3-6], and the genes encoding aggrecan $(A C A N)$ [7-9], Indian Hedge$\mathrm{Hog}(I H H)$ [10] and Natriuretic Peptide Precursor C (Natriuretic Peptide, type C, NPPC) [11]. Most of these conditions were unknown to paediatricians at the time of their training, and there is still limited information about the respective phenotypic presentations. The fast development in this field has made most diagnostic algorithms in paediatric textbooks outdated.

A working group of the Paediatric Association of the Netherlands (4 paediatric endocrinologists, one representative each of general paediatrics, clinical genetics and primary youth health care) prepared a new guideline for practising general paediatricians on the diagnostic approach of children with GF and tall stature (2016-2018). Procedures are described in the online supplementary Information, pg 2-3 (for all online suppl. material, see www. karger.com/doi/10.1159/000499915). The present minireview is based on the section on GF.

The main aim of this mini-review is to offer a guideline to the general paediatrician for a step-by-step diagnostic approach of the child referred for GF (Fig. 1). It starts with the child referred under the suspicion of being unusually short or growing unusually slowly (irrespective of the precise actual HSDS or recent HSDS change) or the child who develops abnormal growth during follow-up for another medical condition. The main reason for a relatively loose inclusion criterion is that many pathologic conditions can present with a growth curve within the normal range. For example, girls with Turner syndrome (TS) often have a normal height for population and target height (TH) in the first years of life [12], and some may have a height within the population range up to adolescence [13].

In the assessment of a child's individual growth curve, the clinician essentially aims at answering 3 questions: (1) how unusual is the child's height compared with the appropriate growth diagram?; (2) how unusual is the child's height compared with the height of the biological parents (expressed as $\mathrm{TH}$ )?; and (3) how unusual is the child's growth pattern over the foregoing years compared with the SD scores (SDS) lines (or centiles) on the growth chart? For background information about the choice of growth diagrams, various equations of $\mathrm{TH}$ and assessment of the growth curve, see online supplementary Information, pg 4-6.

\section{Searching for Diagnostic Clues from Medical History, Physical Examination and Growth Curve}

\section{The Structure of the Diagnostic Flow Chart (Fig. 1)}

The diagnostic flowchart starts with the child presenting at the clinic under the suspicion of GF. The clinician is expected to possess some general knowledge of the clinical features of the most relevant causes of GF. For a full list the reader is referred to the International Classification of Pediatric Endocrine Diagnoses [14]. Selected primary and secondary growth disorders that can present with few or atypical clinical features (apparent "isolated short stature") and with a relatively high incidence and clinical relevance are presented in online supplementary Tables 1 and 2, respectively, including the estimated incidence and prevalence in the population, the prevalence in children referred for short stature, and main clinical features.

The clinical assessment consists of a thorough medical history (including the family history), a detailed physical examination and analysis of the individual growth curve $[15,16]$, aimed at collecting diagnostic clues that point into the direction of a primary or secondary growth disorder.

The next step is a screening procedure consisting of an $\mathrm{X}$-ray of the left hand/wrist and laboratory investigations. The X-ray should not only be investigated for skeletal age (bone age, BA) but also for anatomical abnormalities suggestive for a form of skeletal dysplasia $[2-11,17]$. The latter purpose has become more important because of the recent discovery that heterozygosity for mutations in several genes known to be associated with various forms of severe skeletal dysplasia in homozygous carriers can present with few or nonspecific clinical features, but often do show radiological abnormalities.

The cumulative information from the clinical assessment and screening procedure should lead to a list of diagnostic clues for either a primary or a secondary growth disorder. Already in this screening phase, the diagnosis of several conditions can be established, such as TS, CNVs or uniparental disomy (UPD) in girls, and hypothyroidism, coeliac disease (CD) and iatrogenic disorders irre- 


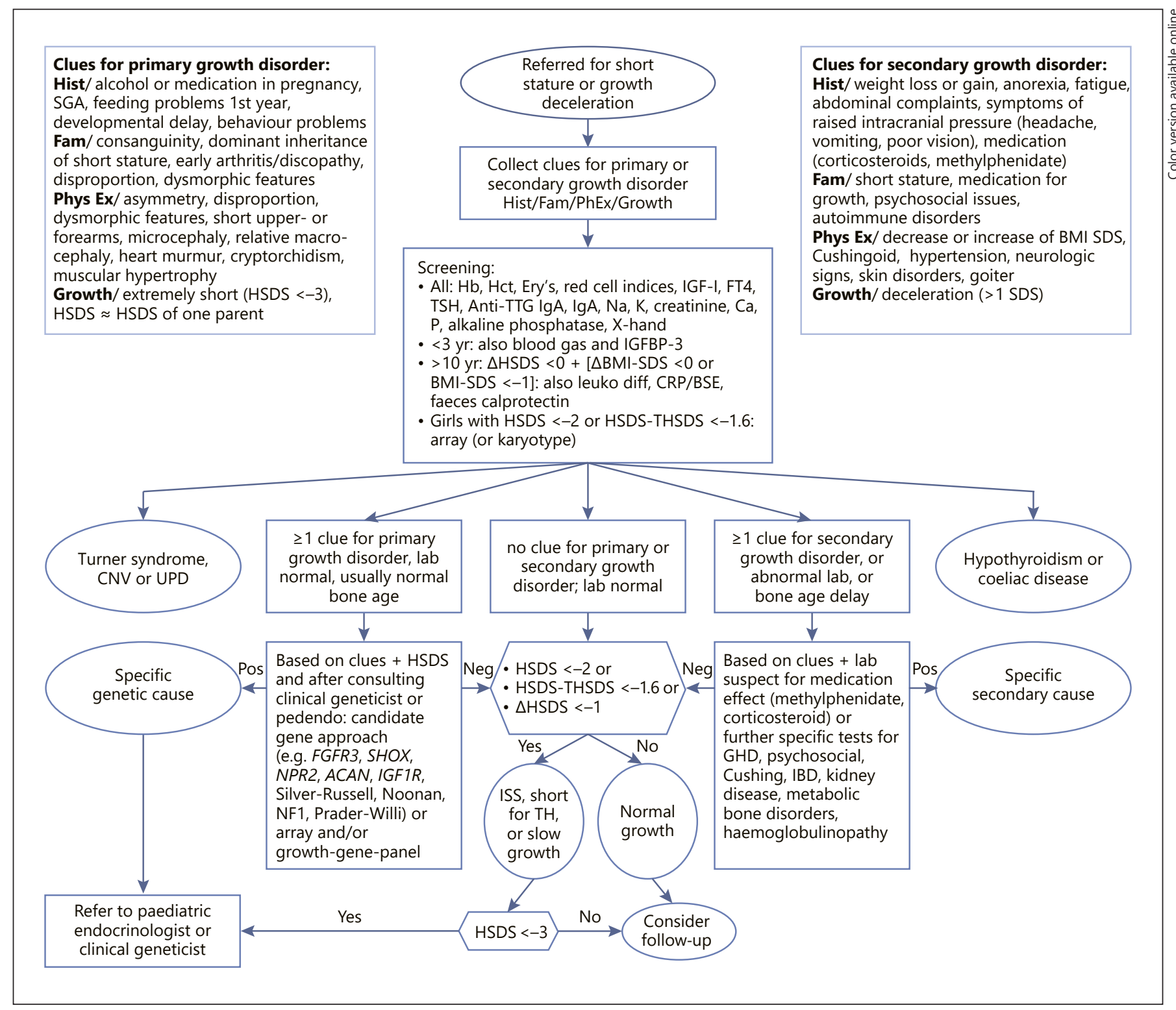

Fig. 1. Flowchart for the diagnostic approach of children referred for GF, or children who develop a growth disorder while attending the clinic for another medical reason. For explanation, see text. SGA, small-for-gestational age; HSDS, height SD score; Hb, haemoglobin; Hct, haematocrit; Anti-TTG IgA, anti-tissue transglutaminase IgA antibodies; BMI, body mass index; SDS, SD score; CNV, copy number variant; UPD, uniparental disomy.

spective of gender (Fig. 1). If the clinician identifies clues for a primary growth disorder, further genetic testing can be performed and when a form of skeletal dysplasia is suspected, a radiographic skeletal survey can be done [18]. If clues for a secondary growth disorder are present, targeted laboratory investigations are warranted, for example, a growth hormone $(\mathrm{GH})$ stimulation test.

Diagnostic Approach in Children

Referred for Growth Failure

\section{Diagnostic Categories}

The 3 major categories of causes of GF are primary growth disorders (assumed to be due to disordered regulation of the epiphyseal growth plate), secondary growth disorders (assumed to be related to changes in external influences on the epiphyseal chondrocytes) and idiopathic short stature (ISS; for more information on ISS, see online suppl. Information pg 5-6), short for parental height 
or slow growth of unknown origin $[19,20]$. While the list of secondary growth disorders has hardly changed over the last decades, the number of primary growth disorders, which can present with mild, minor or even absent additional clinical features has considerably increased due to the expanding use of novel genetic techniques, in particular array analysis (Single Nucleotide Polymorphism microarray [SNP-array] or microarray-based comparative genomic hybridisation [CGH-array]) and whole exome sequencing (WES) [21-23]. Novel genetic causes of GF include heterozygous mutations of genes previously associated with skeletal dysplasias (SHOX, NPR2, ACAN, $I H H, N P P C$ ) [2-11] (online suppl. Table 1). The discovery of this group of conditions, all inherited in an autosomal dominant fashion, has also relevance for the questions to ask at history taking and even more for the clinical features the clinician should look for during the physical examination. Multiple recurrent CNVs (microdeletions and -duplications) have been associated with GF [24-27] at an average diagnostic yield of 13\% [1], but usually children carrying such CNVs had some other clinical features as well.

\section{Relevant Clues in the Medical History of a Child Referred for GF}

On top of a standard full medical history, several questions related to specific features of several pathological causes should be added (specific questionnaire available on request). Examples of specific questions and interpretation of positive answers are shown in Table 1, and a part of these is also shown in Figure 1. Important clues for a primary growth disorder include increased alcohol consumption or medication in pregnancy, low birth weight and/or length (small-for-gestational age) [28], feeding problems or nutrition-related abnormalities (e.g., intolerance, avoidance) in the first year of life, developmental delay, intellectual disability and behavioural problems. Clues for secondary growth disorders include excessive or low weight gain, anorexia, fatigue, abdominal complaints, symptoms related to increased intracranial pressure and medication.

A thorough family history and a schematic pedigree are important components of the medical history, particularly for assessing the likelihood of a primary growth disorder. Consanguinity increases the risk of a recessive disorder, while one apparently affected parent increases the pre-test likelihood of an autosomal dominant condition [3-11]. A novel question to ask is whether there are adult family members affected by early-onset arthritis or discopathy (if positive, this increases the likelihood of a heterozygous ACAN mutation [7]). If one or both parents are short, special attention should be given to their body proportions and dysmorphic features.

The family history can also offer important information regarding the likelihood of a secondary growth disorder, for example, the presence of relatives with short stature (e.g., genetic forms of growth hormone deficiency [GHD]) [29], previous hormonal treatment, psychosocial issues and auto-immune disorders (familial occurrence increases the likelihood of juvenile hypothyroidism and CD).

\section{Relevant Clues in the Physical Examination of a Child} Referred for GF (online suppl. Table 3)

Anthropometry and Pubertal Status

Height, weight, head circumference, sitting height and arm span are essential measures and used to calculate SDS for age and sex. Body mass index (BMI) and sitting height/ height ratio should be calculated and expressed as SDS. Pubertal status should be rated according to Tanner and can also be expressed as SDS [30-32].

Relative macrocephaly can point at Silver-Russell syndrome [33], 3M syndrome [34], neurofibromatosis 1 [35] and TS [36], while microcephaly is also an important clue for the differential diagnosis $[22,28]$. In infants and toddlers, fontanelles and dentition should be evaluated [17].

A relatively high average sitting height/height ratio SDS is seen in most skeletal dysplasias and TS, while a decreased sitting height/height ratio SDS is observed in children with axial segment abnormalities [17], such as biallelic mutations of the gene encoding 3-primephosphoadenosine 5-prime-phosphosulfate synthase 2 (PAPSS2) [37]. Reference data for sitting height/height ratio are available in various countries [38-43]. Measuring sitting height is preferred above measuring lower segment because the latter has a relatively low accuracy and recent reference data for upper/lower segment ratio are scarce [44-47]. The relationship between arm span and height can be expressed as arm span minus height [47], arm span/height ratio [48] or arm span for height [49]. In most primary growth disorders, arm span is shorter than body height, except for heterozygous $A C A N$ mutations [7].

The ratio between length of the upper arm and lower arm (and upper leg versus lower leg) is important for the differentiation between hypochondroplasia (short upper arms and legs, rhizomelia) versus SHOX or NPR2 haploinsufficiency (short forearms and lower legs, mesomelia) $[6,48]$, although in hypochondroplasia short forearms have been reported [50]. 


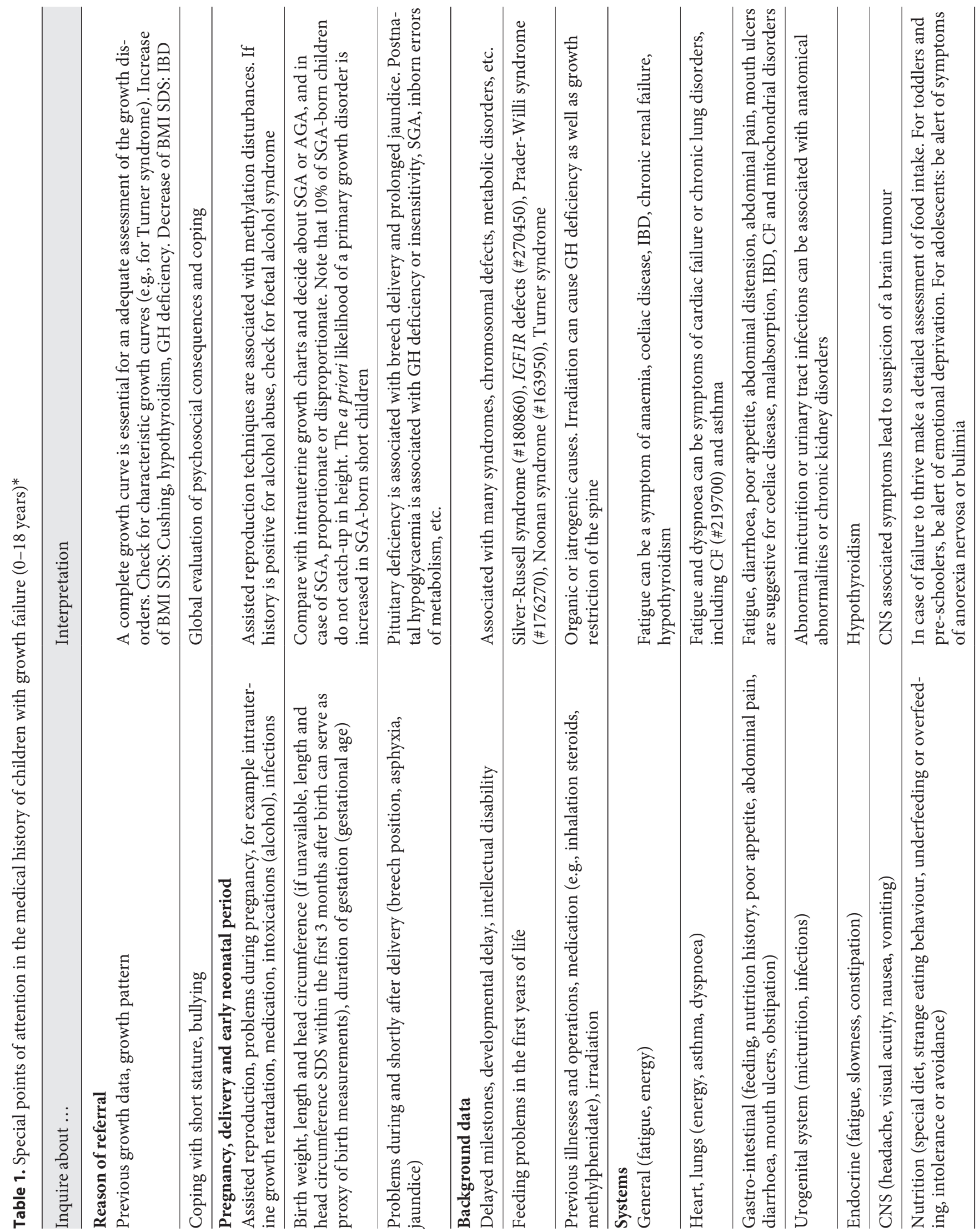




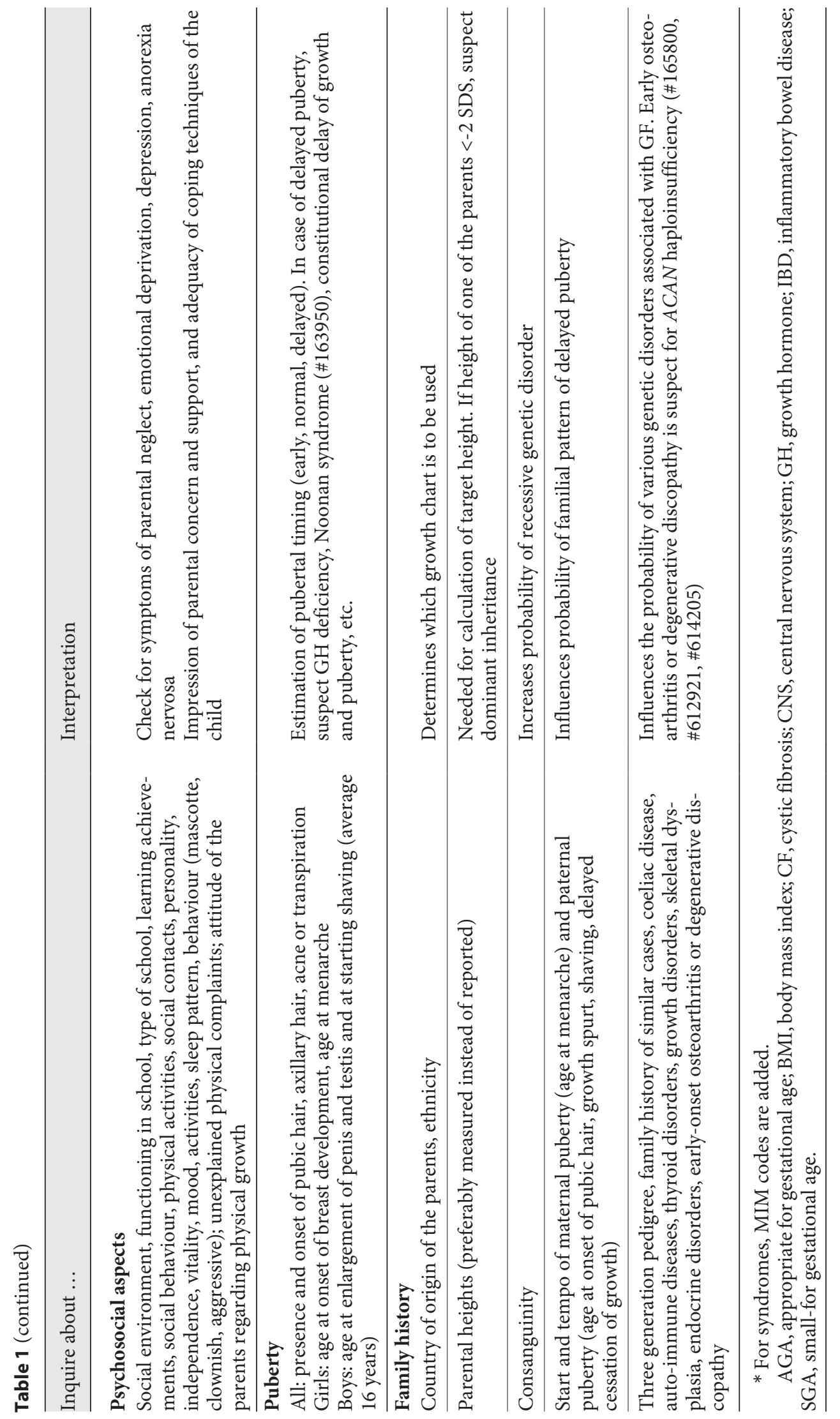


Dysmorphic Features

Special attention should be given to dysmorphic features, since these can offer clues for specific genetic conditions. Selected dysmorphic features are shown in online supplementary Table 3. For more details on dysmorphic features the reader is referred to the London Medical Database via www.Face2Gene.com [51] and a special issue of the Am J Medical Genetics containing 7 reviews on elements of morphology and standard terminology [52-58].

Features of Secondary Growth Disorders

The physical examination can also give important clues for a secondary growth disorder (Fig. 1, online suppl. Table 3). One of the best known examples is a high or recent increase of BMI SDS in combination with growth faltering, suspect of Cushing syndrome, hypothyroidism and GHD. Other examples include Cushingoid appearance (yearly school photographs may be helpful in such cases), hypertension, virilisation and striae in Cushing syndrome, neurologic abnormalities in acquired GHD, goitre in Hashimoto disease and skin disorders in CD. A low or decreasing BMI SDS in combination with growth faltering is a possible symptom for Crohn's disease [5962 ], other chronic systemic illnesses or anorexia nervosa.

\section{Interpretation of the Growth Curve}

The clinician should be persevering in collecting as many as possible growth data from the foregoing years, in order to get a good picture of the growth curve. Several growth disorders are characterized by a specific growth pattern. For example, TS [12, 13, 63, 64], Noonan syndrome $[65,66]$ and probably also haploinsufficiency of SHOX [48], NPR2 [6], ACAN [7], IHH [10] and NPPC [11] usually present with a growth curve starting with a low or low-normal birth length, decreasing length SDS for 2-3 years, followed by a stable HSDS in childhood and a further HSDS decrease during adolescence. An HSDS similar to the height of one of the parents obviously increases the likelihood of a dominant condition. It is plausible that a stable but extremely short stature (HSDS $<-3$ ) increases the likelihood of a primary growth disorder [21], while growth faltering is more compatible with severe GHD or GH insensitivity [29] or other secondary growth disorders.

\section{Radiologic Investigations}

Conventionally, an X-ray of the left hand and wrist is made in a child referred for GF for determination of skeletal age (bone age). This can either be done manually

Diagnostic Approach in Children

Referred for Growth Failure with an atlas $[67,68]$ or with an automated method [69]. In most primary growth disorders, bone age is close to chronological age. In children with heterozygous ACAN mutations, bone age is usually advanced [7], although later reports have shown that bone age can also be delayed $[70,71]$. We suggest that an assessment of anatomical abnormalities be made by the radiologist. Several "novel" disorders can present with such abnormalities, summarized in Table 2 . When a skeletal dysplasia is suspected, a skeletal survey is indicated [18], although presently an exome-based gene panel for skeletal dysplasias may be more efficient to establish a specific diagnosis [72].

\section{Laboratory Screening}

If the diagnostic clues from the clinical assessment suggest the presence of a specific diagnosis, targeted laboratory investigations should be performed. In the absence of any diagnostic clues, the standard recommendations in textbooks (e.g., [73-75]), practice guidelines $[15,16]$ and the ISS consensus statement [76] have been to perform laboratory screening to detect a subclinical chronic illness that initially can present as isolated GF. The diagnostic yield of most components of this screening procedure is probably very low in children without any abnormality in the clinical evaluation and with a normal growth velocity [77], but on the other hand, the clinician would not like to miss a clinically relevant diagnosis. This situation has led to a wide variation between paediatric practices [78, 79].

In the absence of experimental evidence supporting the use of any component of conventional laboratory screening, we tried to assess the pre-test probability of the presence of a chronic medical condition in a child referred for GF. After accepting the 8 priority conditions identified by a French interdisciplinary expert group [80] (CD, Crohn's disease, craniopharyngioma, juvenile nephronophtisis, TS, GHD with pituitary stalk interruption syndrome, infantile cystinosis and hypothalamic-optochiasmatic astrocytoma), we analysed the published results of studies on the diagnostic yield of laboratory screening (online suppl. Table 4), collected anecdotal evidence, assessed implications for treatment and followup, and estimated cost. The resulting list of laboratory investigations to perform in each child referred for GF, as well as investigations to be performed in specific subgroups, is shown in Table 3 and discussed in the following paragraphs. 


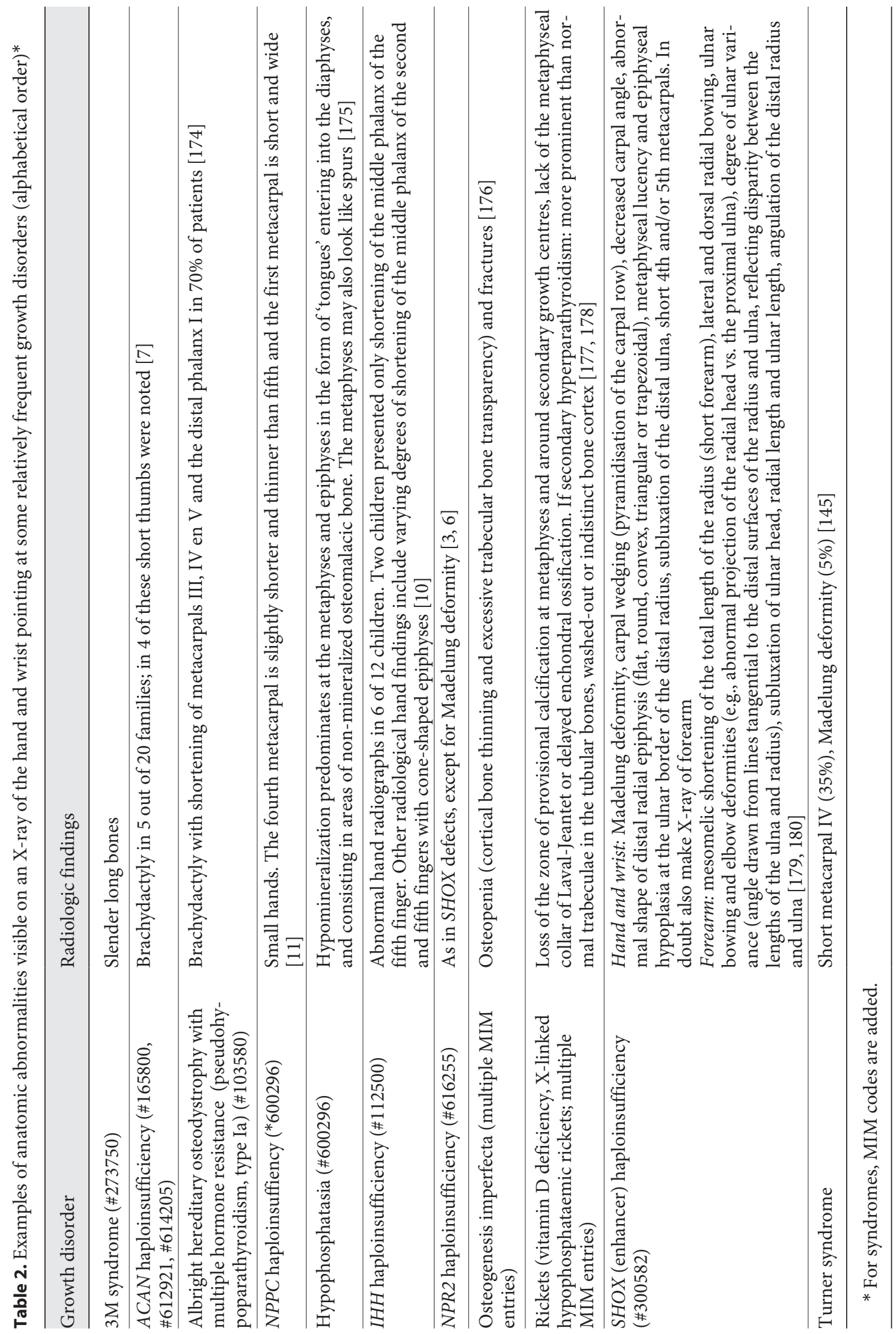


Table 3. Laboratory screening for children referred for growth failure

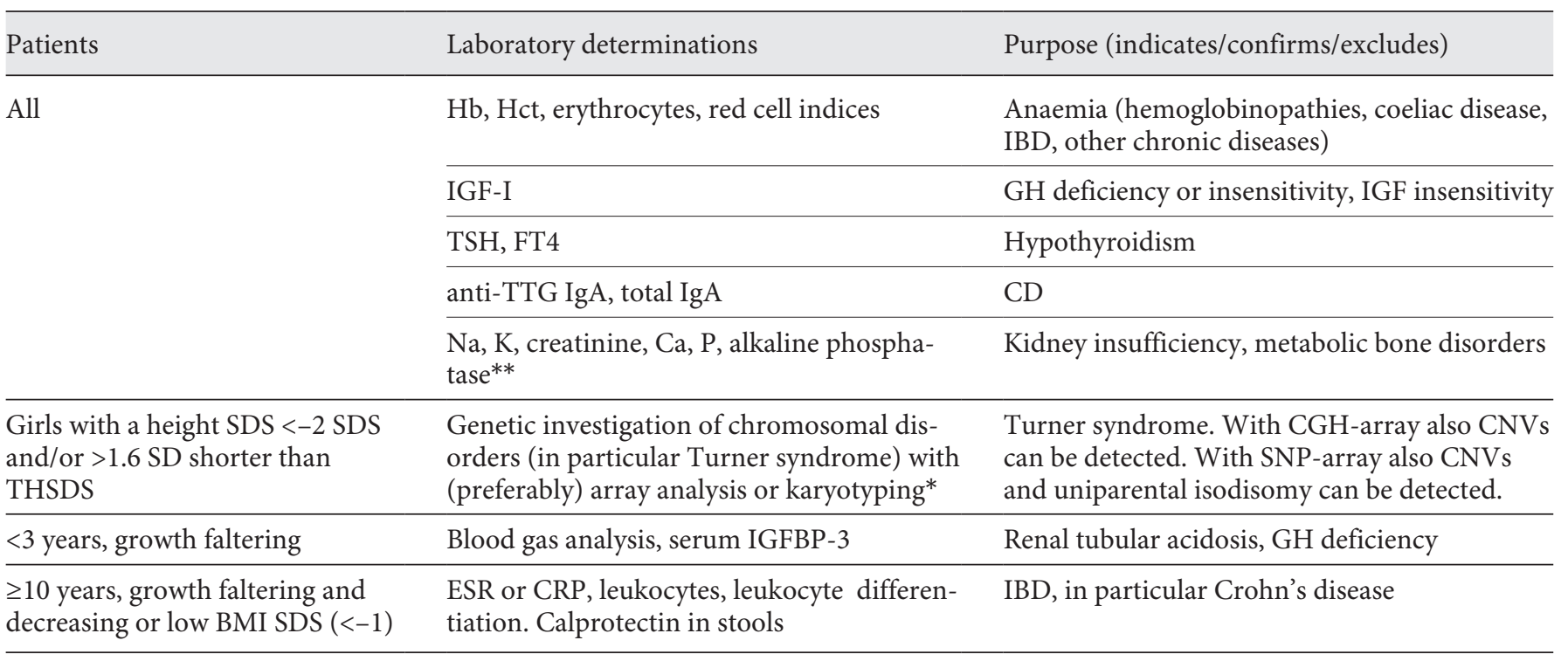

* In girls with clinical suspicion of Turner syndrome with negative result of first line genetic testing (array analysis or karyotyping) a FISH test can be performed on a buccal swab, saliva or urine.

** Basic and comprehensive metabolic panels are bundled in some hospitals and can be less expensive than individual tests.

$\mathrm{Hb}$, haemoglobin; Hct, haematocrit; IBD, inflammatory bowel disease; anti-TTG IgA, anti-tissue transglutaminase IgA antibodies; $\mathrm{CD}$, Coeliac disease; $\mathrm{Na}$, sodium; $\mathrm{K}$, potassium; $\mathrm{Ca}$, calcium; $\mathrm{P}$, phosphate; $\mathrm{CNV}$, copy number variant.

\section{Laboratory Investigations in All Children Referred for} GF

Haematology (Haemoglobin, Haematocrit, Erythrocytes, Red Cell Indices)

Anaemia (decreased haemoglobin [Hb] concentration), with or without abnormalities in haematocrit and red cell indices (mean corpuscular volume, mean corpuscular haemoglobin, mean corpuscular haemoglobin concentration and red cell distribution width) can be an indicator of a chronic illness, iron deficiency, haemoglobinopathy (e.g., thalassaemia, sickle cell anaemia), CD or inflammatory bowel disease (IBD).

Thalassaemia and sickle cell anaemia are in almost all cases limited to individuals of Mediterranean, African or Asian origin and can be associated with GF $[81,82]$. Usually the diagnosis is already known before GF is apparent. If a form of haemoglobinopathy is suspected in a child belonging to a population at risk, serum iron and ferritin as well as $\mathrm{Hb}$ electrophoresis can be added [83].

\section{Serum Insulin-Like Growth Factor (IGF-I)}

While children with severe congenital GHD usually can be diagnosed clinically at an early age based on typical clinical features shortly after birth and a rapid onset of decreasing HSDS [29], children with less severe idiopathic isolated GHD have a more variable growth pattern, which is difficult to distinguish from late maturing children. They can even show a growth pattern characterized by several years of growth faltering followed by stable but low HSDS, particularly if TH is relatively high [84]. Acquired GHD is usually caused by cranial tumours or other space occupying lesions, or their treatment modalities, and usually presents with growth faltering [85] in combination with increasing BMI SDS.

GHD is one of the most frequently detected diagnoses in children with isolated GF (online suppl. Table 4). The diagnosis of idiopathic isolated GHD contains almost always an element of uncertainty and we therefore prefer to assign a degree of likelihood of GHD based on clinical features, growth pattern, delayed bone age, serum IGF-I and insulin-like growth factor binding protein 3 (IGFBP-3), exclusion of other causes and the serum GH response to 2 stimulation tests (only in the first week of life single random GH levels can be used for the diagnosis [86]). If GHD is considered sufficiently likely, GH treatment can be started. The key element of the diagnosis - the maximum serum GH during $2 \mathrm{GH}$ stimulation tests - is known to have a low specificity $[17,76,87]$, so that false-positive re- 
sults can easily occur [88-90]. We appreciate that one of the unresolved issues in the literature is the use of sex steroid priming prior to stimulation tests [17, 90-94], but believe that priming is needed in prepubertal children (in our country from 8 [girls] or 10 [boys] years onwards) to limit the percentage of false-positive results.

Serum IGF-I is commonly used as a screening parameter $[95,96]$ with an average positive and negative likelihood ratio of 2.5 and 0.5 , respectively [97]. The interpretation of serum IGF-I is dependent on the assay [98], availability of adequate reference diagrams enabling conversion to SDS for age, sex and pubertal stage, attention to other factors influencing IGF-I concentration (nutritional status, liver function, thyroid function and pubertal stage) $[96,99-101]$ and the a priori likelihood of GHD based on clinical information (balance of positive and negative clues from medical history, physical examination and growth analysis). If IGF-I SDS is $>0$, GHD is unlikely.

Studies on the potential additive value of serum IGFBP-3 determinations at the screening stage are contradictory [97, 102-106], except for infants and young toddlers $[76,96,107,108]$. We advise to repeat a baseline measurement of IGF-I and add an IGFBP-3 determination when a GH stimulation test is carried out, except in children $<3$ years, where IGFBP- 3 can better be added even in the screening phase $[76,96]$.

The results of serum IGF-I and IGFBP-3 can also suggest other defects in the GH-IGF-I axis. Low IGF-I and IGFBP-3 in combination with a normal or elevated GH peak on stimulation is an indicator of either bioinactive $\mathrm{GH}$ (Kowarski syndrome) or one of the forms of GH insensitivity (caused by mutations of GHR, STAT5B, STAT3, IGFALS or IGF1) [22, 109]. In such cases, an IGFI generation test can be useful, despite its limitations [110-113]. A serum IGF-I in the upper half of the normal range or higher is consistent with a heterozygous mutation or deletion of IGF1R [114], bi-allelic defect of PAP$P A 2$ [115] or a form of Silver-Russell syndrome, including IGF2 defect [116].

\section{FT4, TSH}

In countries where no neonatal screening for congenital hypothyroidism is performed, postnatal GF is an important clue to the diagnosis. Neonatal screening based on thyroid stimulating hormone (TSH) determination can only detect primary hypothyroidism, while the combination of thyroxine (T4) and TSH screening detects both primary and secondary hypothyroidism [117].

Acquired juvenile hypothyroidism is rare, particularly below 10 years of age, and usually caused by Hashimoto thyroiditis. A positive family history for acquired autoimmune thyroid disorders and an increasing BMI SDS in combination with growth faltering are important diagnostic clues. It can take several years before HSDS gets below -2 , depending on THSDS $[118,119]$. Treatment with L-thyroxine leads to almost instantaneous normalisation of the symptoms and signs and to a fast catch-up growth $[118,119]$.

\section{Anti-Anti-Tissue Transglutaminase IgA Antibodies} and Total IgA

Arguments in favour of determining anti-tissue transglutaminase IgA antibodies and total IgA for screening of $\mathrm{CD}$ include the high incidence in the population (on average $0.7 \%$ of the world population) [120] and a high diagnostic yield in children with GF (2-15\%) [121-128]. However, most children diagnosed with CD have a height within the normal range (mean HSDS at presentation -0.5 SDS [129]) and only a tiny average decrease of HSDS (0.07 SDS/year) in the first 2 years of life [130].

Obviously, the chance of finding CD is greater if one or more of the typical characteristics of CD are present, such as distended abdomen, abnormal defaecation pattern, fatigue, anorexia, anaemia, skin disorders (e.g., dermatitis herpetiformis), mouth ulcers, and so on (Table 1, online suppl. Table 3) [126]. Laboratory screening should be performed in any child referred for GF, irrespective of current HSDS or its deflection [129]. The determination of anti-tissue transglutaminase IgA plus total IgA has sufficient sensitivity [131, 132]. If there is clinical suspicion of $\mathrm{CD}$, one can consider additional determination of antiendomysium antibodies. In case of IgA deficiency, IgG antibodies should be tested.

\section{$\mathrm{Na}, \mathrm{K}$, Creatinine}

Growth faltering can be the first sign of a chronic kidney disease $[80,133]$, such as infantile cystinosis (median age at diagnosis 18-21 months) [134-138] and juvenile nephronophthisis (mean [SD] age at diagnosis 9.3 [3.0] years) [139]. Screening for urinary glucose, protein, blood and sediment does not have an additive value.

\section{Serum Ca, P, and Alkaline Phosphatase}

In theory, several disorders of calcium-phosphate metabolism (e.g., vitamin D deficiency [rickets], hypophosphatasia, hypophophataemic rickets, [pseudo]hypoparathyroidism and osteogenesis imperfecta) can be associated with isolated GF $[22,140]$, but their low prevalence and usually present additional clinical features render the pre-test probability very low. We have not found reports 
showing that isolated GF can be the presenting sign of any of these disorders, but we collected anecdotal information indicating that this can occur, so that we decided to keep these determinations in the screening panel.

Laboratory Investigations with Insufficient Evidence to Be Included into the Screening Panel

In contrast to most textbooks and reviews (e.g., [15$17,76]$ ), we have omitted the determination of thrombocyte and leukocyte counts, leukocyte differentiation and erythrocyte sedimentation rate or C-reactive protein, liver function tests and urine analysis from laboratory screening. However, if the liver is enlarged at physical examination or if a metabolic disorder is suspected for other reasons, liver function tests, serum cholesterol, triglycerides, uric acid and a comprehensive metabolic panel should be considered.

\section{Additional Laboratory Investigation in Children} $<3$ Years: Blood Gas and Serum IGFBP-3

A retrospective study on growth and age at diagnosis of children with renal tubular acidosis [141] showed that they can indeed present with isolated growth faltering, but almost always before the age of 3 years [15]. We therefore maintain our advice to limit blood gas testing to children below 3 years. As mentioned earlier, serum IGFBP-3 is useful as screening parameter for GHD in this age group.

\section{Additional Laboratory Investigations in Teenagers}

(>10 Years) who Present with Growth Faltering and

Decreasing BMI or a BMI SDS <-1: Leukocyte Count and Differentiation, Faecal Calprotectin

One of the priority target conditions for growth monitoring [80] is IBD, particularly Crohn's disease. While IBD usually presents with a combination of intestinal complaints (e.g., abdominal pain, diarrhoea, weight loss, and in patients with colitis ulcerosa also rectal blood loss) and growth faltering [142], the latter can also occur before the onset of gastro-intestinal symptoms [59-62, 143], usually in combination with a low or decreasing BMI SDS $[59,80]$.

We advise to specifically collect information on intestinal complaints (e.g., abdominal pain, blood and mucus in the stool and fatigue) at history taking (Table 1), but speculate that this may not be sufficient to diagnose all children with IBD at an early stage. Therefore, laboratory screening (leukocyte count, leukocyte-differentiation, one or both inflammation parameters [erythrocyte sedimentation rate and/or C-reactive protein] and determi- nation of faecal calprotectin) in teenagers with an a priori increased risk appears indicated, that is, in those $\geq 10$ years with GF and a decreased or decreasing BMI SDS. Since IBD can also (but rarely) occur at a younger age, these laboratory tests can also be considered in young children with such pattern of linear growth and BMI SDS.

\section{Additional Testing in All Girls Referred for GF with a}

HSDS <-2 AND/OR a Height 1.6 SD Below THSDS

TS is a well-known and relatively frequent cause of short stature in girls (online suppl. Table 1), but the average age at diagnosis is still late $[64,144]$. Timely diagnosis of TS enables early detection and management of concomitant anatomical disorders, for example, coarctation of the aorta, abnormal aorta valves and anatomical abnormalities of the urogenital system [145]. Further, timely diagnosis enables early treatment with $\mathrm{GH}$, which increases adult height gain [146].

Usually one or more of the characteristic Turner stigmata are present in girls with TS [145], but $2-3 \%$ present with apparent isolated GF $[147,148]$. HSDS can be within the normal range (mean HSDS ranges from -2.8 to -2.2 with an SD of approximately 1.0 [149-151]) and growth monitoring criteria have a sensitivity of $52-75 \%$ for TS [150,152-154]. The pre-test probability of TS in a girl with apparent isolated GF is higher in the presence of a specific growth pattern (mean birth length SDS -0.7, fast decrease of HSDS in the first year [to -1.6 SDS] followed by a more gradual decrease at 2 and 3 years, a stable or slightly decreasing HSDS up to 10 years and an absent pubertal growth spurt $[12,13])$, a low birth length $[36$, 155-157], a large distance between HSDS and THSDS $(>2)[149,152,156]$, a relatively high sitting height/height ratio [151]), normal head circumference $[36,158,159]$ and pubertal delay or primary amenorrhoea [156].

Traditionally, serum LH and FSH have been determined to estimate the likelihood of TS, but the diagnostic value is limited to girls of $0-2$ years of age or in girls $\geq 10$ years, and even in those age ranges, false-negative results are not rare [160].

While karyotyping has been the standard genetic technique for detecting TS, and still advised in the recent consensus on TS [145], we favour array analysis (SNP-array or CGH-array) because of the following reasons: (1) Similar sensitivity for virtually all TS variants [161]; (2) possibility to diagnose other chromosomal aberrations (e.g., $\mathrm{XY} / \mathrm{X}$ ) and CNVs (microdeletions and -duplications) at other chromosomal locations related to growth; (3) if a SNP-array is used, also most forms of uniparental isodisomy can be detected [162]; and (4) lower cost because 
the assay is less labour-intensive. Thus, the high "number needed to test" $(\approx 40)$ using karyotyping in girls with isolated GF $[147,148]$ can be considerably decreased by using SNP arrays, which can detect CNVs in up to $13 \%$ [1, 22, 24-27] and UPDs. However, there are also disadvantages of array analysis, such as the identification of a CNV of uncertain significance or of "susceptibility loci," which may lead to further testing of the patient and parents.

Since a large distance between HSDS and THSDS is a better predictor for TS than a low HSDS $[149,152]$ and girls with TS can have a height within the normal range, we propose genetic testing for TS in girls if $\mathrm{HSDS}<-2$ OR $>1.6 \mathrm{SD}$ below THSDS. If in a girl with high clinical suspicion of TS the array analysis or karyotype yields a normal result, a FISH Y/X can be performed, preferably in another tissue (e.g., a buccal smear or urinary sample).

\section{Preliminary Decision on Likelihood of Primary or Secondary Cause Followed by Further Testing}

After collecting diagnostic clues from the medical history, physical examination, growth analysis and radiological and laboratory screening, 5 diagnoses can be made: hypothyroidism, CD, TS, or a known pathogenic CNV or UPD in girls (Fig. 1). If none of these disorders have been found, the paediatrician should estimate the likelihood of a primary growth disorder or a secondary growth disorder based on the collection of diagnostic clues. Further diagnostic steps are dependent of this estimation.

\section{Diagnostic Approach if $\geq 1$ Clue for a Primary Growth}

Disorder

If some form of primary growth disorder appears likely, we suggest that the general paediatrician designs the further diagnostic approach in collaboration with a clinical geneticist or paediatric endocrinologist. In boys, and in girls in whom karyotyping was used for genetic screening for TS, it would be logical to first consider array analysis $[1,23,109,163]$. If negative, one can decide on a candidate gene approach if the child is disproportionate and/ or shows dysmorphic features that are typical of one of the established genetic causes of short stature (online suppl. Table 1).

However, the phenotypic profiles of various genetic disorders show considerable overlap (e.g., similar clinical features of children with SHOX and NPR2 haploinsufficiency [6], and in children with mild or absent physical signs unpredicted mutations in multiple genes can be found $[9,23,164])$. Therefore, a WES-based, growth-spe- cific gene panel ("singleton WES with targeted phenotype-driven analysis" [72]) may be a more cost-effective approach [23, 72, 165-169] (for a detailed flowchart, see [23]). Sanger sequencing or WES (with present technology) can only diagnose mutations (including very small deletions and splicing defects), but not larger deletions within or around the gene, so that for the diagnosis of SHOX haploinsufficiency usually first a specific multiplex ligation-dependent probe amplification (MLPA) test [170] is performed to detect deletions or duplications of exons and gene enhancers, if normal followed by Sanger sequencing $[2,171]$. MLPA tests are available for a large number of genes.

If singleton WES in the child does not lead to a diagnosis, a trio WES can be considered (i.e., WES on DNA from patient and both parents), which may lead to the diagnosis of unexpected known or novel conditions [9, $21,22]$. If this is negative, further testing can be discontinued, until future techniques become available for clinical use (e.g., RNA sequencing, methylation arrays and whole genome sequencing [172]).

Establishing the diagnosis can have important consequences for treatment decisions, for example, withholding $\mathrm{GH}$ treatment in cancer predisposition conditions (e.g., Bloom syndrome, Fanconi anaemia) [173], additional assessment of possible comorbidities and genetic counselling.

\section{Diagnostic Approach if $\geq 1$ Clue for a Secondary}

Growth Disorder

If some form of secondary growth disorder seems likely, one can either establish a diagnosis based on medical history alone, - for example, effect of medication (methylphenidate, steroids), anorexia nervosa, or psychosocial dwarfism - or perform further specific testing for other conditions. If clinical features, growth pattern and serum IGF-I suggest GHD, 2 GH stimulation tests, serum IGFBP- 3 and a repeat serum IGF-I are indicated, and followed by a brain MRI if GHD is diagnosed $[90,95]$.

\section{Approach if There Are No Clues for Any Specific}

Growth Disorder, or Negative Results of Evaluation of Primary and Secondary Causes

In the absence of any diagnostic clues, or if further testing is negative, the next step is dependent on the degree of abnormality of the growth pattern. If HSDS $<-2$, one can apply the diagnostic label ISS, either familial or non-familial. If height is in the lower normal range but $>1.6$ SDS shorter than THSDS, one can call this "short for TH of unknown origin." If HSDS and HSDS-THSDS are still in 
the normal range but growth is slow in a fully asymptomatic child, most clinicians would like to make a follow-up appointment. In extreme cases, for example if HSDS $<-3$, we suggest to refer the child to a specialized growth centre. We advise to keep track of severely short patients in whom no cause could be found with current technology, and to consider the application of novel forms of (epi)genetic testing when these become available.

\section{Conclusions}

The recent discovery of a number of novel genetic disorders associated with GF has not only changed its differential diagnosis but also has consequences for the content of the medical history, physical examination, assessment of the growth curve, radiological assessment and laboratory screening. We propose a stepwise diagnostic approach, consisting of collecting diagnostic clues for a primary or secondary growth disorder, radiological and laboratory screening, interpretation of the clues and screening results, and if indicated, further genetic or biochemical testing. The relatively high prevalence of dominant genetic causes of GF with subtle dysmorphic features and mild body disproportion emphasises the need of a thorough search for dysmorphisms and of including head circumference, sitting height and arm span measurements into the physical examination. SNP-arrays and exome-based growth-specific gene panels are useful tools if a primary growth disorder is suspected.

\section{Acknowledgements}

The authors thank I.M. Mostovaya and A.M.M. Vaes (Knowledge Institute of the Dutch Association of Medical Specialists) for their advisory and supportive role in the establishment of the Dutch Guideline on Triage and Diagnosis of Growth Disturbances in Children. We acknowledge the constructive comments on previous drafts of the Guideline by several members of the Dutch Paediatric Association (M.J.E. Walenkamp, C.de Bruin, A.C.S. Hokken-Koelega, T.G.J. Derks), as well representatives of the Dutch Youth Health Care Physicians, Netherlands Association of Internal Medicine, Dutch Society for Clinical Genetics, and Dutch Society for Clinical Chemistry and Laboratory Medicine.

\section{Dutch Working Group on Triage and Diagnosis of Growth Disorders in Children}

Other members include Boudewijn Bakker (Department of Paediatrics, University Medical Center Utrecht, Utrecht, the Netherlands), Sarina G. Kant (Department of Clinical Genetics, Leiden
University Medical Center, Leiden, the Netherlands), Roelof J. Odink (Department of Paediatrics, Catharina Hospital, Eindhoven, and Department of Paediatrics, Máxima Medical Centre, Eindhoven, The Netherlands), and Jeroen A. de Wilde (Department of Primary Health Care, Leiden University Medical Center, Leiden, the Netherlands).

\section{Statement of Ethics}

The authors have no ethical conflicts to disclose.

\section{Disclosure Statement}

J.M.W. is member of advisory boards of OPKO, Merck, Ammonett, Aeterna Zentaris, Agios and Biomarin and received speaker's fees from Pfizer, Versartis, Sandoz, Lilly, Novo Nordisk, JCR, Merck and Ipsen. The other authors have no conflicts of interest to disclose.

\section{Funding Source}

The development of the guideline was supported by a grant from the Foundation of Quality Funding for Medical Specialists (SKMS).

\section{Author Contributions}

J.M.W. was one of the 2 leading authors of the Dutch guideline and took the lead in writing the manuscript. W.O. chaired the Committee responsible for the guideline and was involved in all subsequent versions of the guideline and the manuscript. G.A.K. was member of the Committee and revised multiple versions of the guideline and manuscript. All authors and members of the Committee agree with the submitted manuscript.

References

Horm Res Paediatr 2019;91:223-240
1 Homma TK, Krepischi AC, Furuya TK, Honjo RS, Malaquias AC, Bertola DR, et al. Recurrent Copy Number Variants Associated with Syndromic Short Stature of Unknown Cause. Horm Res Paediatr. 2018;89(1):13-21.

2 Marchini A, Ogata T, Rappold GA. A Track Record on SHOX: From Basic Research to Complex Models and Therapy. Endocr Rev. 2016 Aug;37(4):417-48.

3 Vasques GA, Amano N, Docko AJ, Funari MF, Quedas EP, Nishi MY, et al. Heterozygous mutations in natriuretic peptide receptor-B (NPR2) gene as a cause of short stature in patients initially classified as idiopathic short stature. J Clin Endocrinol Metab. 2013 Oct;98(10):E1636-44.
Diagnostic Approach in Children

Referred for Growth Failure
DOI: $10.1159 / 000499915$ 
4 Amano N, Mukai T, Ito Y, Narumi S, Tanaka $\mathrm{T}$, Yokoya S, et al. Identification and functional characterization of two novel NPR2 mutations in Japanese patients with short stature. J Clin Endocrinol Metab. 2014 Apr; 99(4):E713-8

5 Wang SR, Jacobsen CM, Carmichael H, Edmund $\mathrm{AB}$, Robinson JW, Olney RC, et al. Heterozygous mutations in natriuretic peptide receptor-B (NPR2) gene as a cause of short stature. Hum Mutat. 2015 Apr;36(4):474-81.

6 Hisado-Oliva A, Garre-Vázquez AI, Santaolalla-Caballero F, Belinchón A, BarredaBonis AC, Vasques GA, et al. Heterozygous NPR2 Mutations Cause Disproportionate Short Stature, Similar to Léri-Weill Dyschondrosteosis. J Clin Endocrinol Metab. 2015 Aug;100(8):E1133-42.

7 Gkourogianni A, Andrew M, Tyzinski L, Crocker M, Douglas J, Dunbar N, et al. Clinical Characterization of Patients With Autosomal Dominant Short Stature due to Aggrecan Mutations. J Clin Endocrinol Metab. 2017 Feb;102(2):460-9.

8 Hauer NN, Sticht H, Boppudi S, Büttner C, Kraus C, Trautmann U, et al. Genetic screening confirms heterozygous mutations in ACAN as a major cause of idiopathic short stature. Sci Rep. 2017 Sep;7(1):12225.

9 Hauer NN, Popp B, Schoeller E, Schuhmann S, Heath KE, Hisado-Oliva A, et al. Clinical relevance of systematic phenotyping and exome sequencing in patients with short stature. Genet Med. 2018 Jun;20(6):630-8.

10 Vasques GA, Funari MF, Ferreira FM, AzaCarmona M, Sentchordi-Montané L, Barraza-García J, et al. IHH Gene Mutations Causing Short Stature With Nonspecific Skeletal Abnormalities and Response to Growth Hormone Therapy. J Clin Endocrinol Metab. 2018 Feb;103(2):604-14.

11 Hisado-Oliva A, Ruzafa-Martin A, Sentchordi L, Funari MF, Bezanilla-López C, AlonsoBernáldez M, et al. Mutations in C-natriuretic peptide (NPPC): a novel cause of autosomal dominant short stature. Genet Med. 2018 Jan; 20(1):91-7.

12 Davenport ML, Punyasavatsut N, Stewart PW, Gunther DF, Sävendahl L, Sybert VP. Growth failure in early life: an important manifestation of Turner syndrome. Horm Res. 2002;57(5-6): 157-64.

13 Ranke MB, Pflüger $\mathrm{H}$, Rosendahl W, Stubbe $\mathrm{P}$, Enders H, Bierich JR, et al. Turner syndrome: spontaneous growth in 150 cases and review of the literature. Eur J Pediatr. 1983 Dec;141(2):81-8.

14 Ranke MB, Quigley CA. International Classification of Pediatric Endocrine Diagnoses. Rotterdam: Growth Analyser; 2016. www. icped.org.

15 Oostdijk W, Grote FK, de Muinck KeizerSchrama SM, Wit JM. Diagnostic approach in children with short stature. Horm Res. 2009; 72(4):206-17.
16 Rogol AD, Hayden GF. Etiologies and early diagnosis of short stature and growth failure in children and adolescents. J Pediatr. 2014 May;164(5 Suppl):S1-14.e6.

17 Collett-Solberg PF, Jorge AA, Boguszewski MC, Miller BS, Choong CS, Cohen P, et al. Growth hormone therapy in children; research and practice - A review. Growth Horm IGF Res. 2019 Feb;44:20-32.

18 Kant SG, Grote F, de Ru MH, Oostdijk W, Zonderland HM, Breuning MH, et al. Radiographic evaluation of children with growth disorders. Horm Res. 2007;68(6):310-5.

19 Wit JM, Ranke MB, Kelnar CJ. ESPE Classification of Paediatric Endocrine Diagnoses. Horm Res. 2007;68(Suppl 2):1-120.

20 Baron J, Sävendahl L, De Luca F, Dauber A, Phillip M, Wit JM, et al. Short and tall stature: a new paradigm emerges. Nat Rev Endocrinol. 2015 Dec;11(12):735-46.

21 Dauber A, Rosenfeld RG, Hirschhorn JN. Genetic evaluation of short stature. J Clin Endocrinol Metab. 2014 Sep;99(9):3080-92.

22 Wit JM, Oostdijk W, Losekoot M, van Duyvenvoorde HA, Ruivenkamp CA, Kant SG. Mechanisms in endocrinology: novel genetic causes of short stature. Eur J Endocrinol. 2016 Apr;174(4):R145-73.

23 Murray PG, Clayton PE, Chernausek SD. A genetic approach to evaluation of short stature of undetermined cause. Lancet Diabetes Endocrinol. 2018 Jul;6(7):564-74.

24 Zahnleiter D, Uebe S, Ekici AB, Hoyer J, Wiesener A, Wieczorek D, et al. Rare copy number variants are a common cause of short stature. PLoS Genet. 2013;9(3):e1003365.

25 van Duyvenvoorde HA, Lui JC, Kant SG, Oostdijk W, Gijsbers AC, Hoffer MJ, et al. Copy number variants in patients with short stature. Eur J Hum Genet. 2014 May;22(5): 602-9.

26 Wit JM, van Duyvenvoorde HA, van Klinken JB, Caliebe J, Bosch CA, Lui JC, et al. Copy number variants in short children born small for gestational age. Horm Res Paediatr. 2014; 82(5):310-8.

27 Canton AP, Costa SS, Rodrigues TC, Bertola DR, Malaquias AC, Correa FA, et al. Genomewide screening of copy number variants in children born small for gestational age reveals several candidate genes involved in growth pathways. Eur J Endocrinol. 2014 Aug; 171(2): 253-62.

28 Finken MJ, van der Steen M, Smeets CC, Walenkamp MJ, de Bruin C, Hokken-Koelega AC, et al. Children Born Small for Gestational Age: Differential Diagnosis, Molecular Genetic Evaluation, and Implications. Endocr Rev. 2018 Dec;39(6):851-94.

29 Alatzoglou KS, Turton JP, Kelberman D, Clayton PE, Mehta A, Buchanan C, et al. Expanding the spectrum of mutations in $\mathrm{GH} 1$ and GHRHR: genetic screening in a large cohort of patients with congenital isolated growth hormone deficiency. J Clin Endocrinol Metab. 2009 Sep;94(9):3191-9.
30 Menke LA, Sas TC, de Muinck Keizer-Schrama SM, Zandwijken GR, de Ridder MA, Odink RJ, et al. Efficacy and safety of oxandrolone in growth hormone-treated girls with turner syndrome. J Clin Endocrinol Metab. 2010 Mar;95(3):1151-60.

31 Joustra SD, van der Plas EM, Goede J, Oostdijk W, Delemarre-van de Waal HA, Hack WW, et al. New reference charts for testicular volume in Dutch children and adolescents allow the calculation of standard deviation scores. Acta Paediatr. 2015 Jun;104(6):e2718.

32 Lawaetz JG, Hagen CP, Mieritz MG, Blomberg Jensen M, Petersen JH, Juul A. Evaluation of 451 Danish boys with delayed puberty: diagnostic use of a new puberty nomogram and effects of oral testosterone therapy. J Clin Endocrinol Metab. 2015 Apr;100(4):1376-85.

33 Wakeling EL, Brioude F, Lokulo-Sodipe O, O'Connell SM, Salem J, Bliek J, et al. Diagnosis and management of Silver-Russell syndrome: first international consensus statement. Nat Rev Endocrinol. 2017 Feb;13(2): 105-24.

34 Clayton PE, Hanson D, Magee L, Murray PG, Saunders E, Abu-Amero SN, et al. Exploring the spectrum of 3-M syndrome, a primordial short stature disorder of disrupted ubiquitination. Clin Endocrinol (Oxf). 2012 Sep; 77(3):335-42.

35 Karvonen M, Saari A, Hannila ML, Lönnqvist T, Dunkel L, Sankilampi U. Elevated head circumference-to-height ratio is an early and frequent feature in children with neurofibromatosis type 1. Horm Res Paediatr. 2013; 79(2):97-102.

36 Sari E, Bereket A, Yeșilkaya E, Baș F, Bundak $\mathrm{R}$, Aydın BK, et al. Anthropometric findings from birth to adulthood and their relation with karyotpye distribution in Turkish girls with Turner syndrome. Am J Med Genet A. 2016 Apr;170A(4):942-8.

37 Oostdijk W, Idkowiak J, Mueller JW, House PJ, Taylor AE, O'Reilly MW, et al. PAPSS2 deficiency causes androgen excess via impaired DHEA sulfation - in vitro and in vivo studies in a family harboring two novel PAPSS2 mutations. J Clin Endocrinol Metab. 2015 Apr; 100(4):E672-80.

38 Tanner JM, Whitehouse RH, Hughes PC, Carter BS. Relative importance of growth hormone and sex steroids for the growth at puberty of trunk length, limb length, and muscle width in growth hormone-deficient children. J Pediatr. 1976 Dec;89(6):1000-8.

39 Prader A, Largo RH, Molinari L, Issler C. Physical growth of Swiss children from birth to 20 years of age. First Zurich longitudinal study of growth and development. Helv Paediatr Acta Suppl. 1989 Jun;52:1-125. 
40 Fredriks AM, van Buuren S, van Heel WJ, Dijkman-Neerincx RH, Verloove-Vanhorick SP, Wit JM. Nationwide age references for sitting height, leg length, and sitting height/ height ratio, and their diagnostic value for disproportionate growth disorders. Arch Dis Child. 2005 Aug;90(8):807-12.

41 de Arriba Muñoz A, Domínguez Cajal M, Rueda Caballero C, Labarta Aizpún JI, Mayayo Dehesa E, Ferrández Longás Á. Sitting height/standing height ratio in a Spanish population from birth to adulthood. Arch Argent Pediatr. 2013 Jul-Aug;111(4):309-14.

42 Bundak R, Bas F, Furman A, Günöz H, Darendeliler F, Saka N, et al. Sitting height and sitting height/height ratio references for Turkish children. Eur J Pediatr. 2014 Jul; 173(7):861-9.

43 Zhang YQ, Li H. Reference charts of sitting height, leg length and body proportions for Chinese children aged 0-18 years. Ann Hum Biol. 2015;42(3):223-30.

44 Wilkins L. Diagnosis and treatment of endocrine disorders in childhood and adolescence. Springfield (Illinois); 1966.

45 Recker BF. Reference charts used frequently by endocrinologists in assessing the growth and development of youth. In: Lifshitz F, editor. Pediatric endocrinology. New York: Marcel Dekker; 1996. pp. 887-932.

46 Pearson VV. Genetics. In Gunn VLN, Nechyba C, editor. The Johns Hopkins Hospital Harriet Lane handbook. Toronto, ON: Mosby; 2002, pp 277.

47 Turan S, Bereket A, Omar A, Berber M, Ozen A, Bekiroglu N. Upper segment/lower segment ratio and armspan-height difference in healthy Turkish children. Acta Paediatr. 2005 Apr;94(4):407-13.

48 Rappold G, Blum WF, Shavrikova EP, Crowe BJ, Roeth R, Quigley CA, et al. Genotypes and phenotypes in children with short stature: clinical indicators of SHOX haploinsufficiency. J Med Genet. 2007 May;44(5):306-13.

49 Gerver WJMdB. R.: Paediatric morphometrics, a reference manual (second extended edition). Maastricht: University Press Maastricht; 2001

50 Song SH, Balce GC, Agashe MV, Lee H, Hong SJ, Park YE, et al. New proposed clinico-radiologic and molecular criteria in hypochondroplasia: FGFR 3 gene mutations are not the only cause of hypochondroplasia. Am J Med Genet A. 2012 Oct;158A(10):2456-62.

51 Face2Gene. London Medical Databases. Boston, MA, USA; 2019.

52 Allanson JE, Biesecker LG, Carey JC, Hennekam RC. Elements of morphology: introduction. Am J Med Genet A. 2009 Jan; $149 \mathrm{~A}(1): 2-5$

53 Allanson JE, Cunniff C, Hoyme HE, McGaughran J, Muenke M, Neri G. Elements of morphology: standard terminology for the head and face. Am J Med Genet A. 2009 Jan; 149A(1):6-28.
54 Hall BD, Graham JM Jr, Cassidy SB, Opitz JM. Elements of morphology: standard terminology for the periorbital region. Am J Med Genet A. 2009 Jan;149A(1):29-39.

55 Hunter A, Frias JL, Gillessen-Kaesbach G, Hughes H, Jones KL, Wilson L. Elements of morphology: standard terminology for the ear. Am J Med Genet A. 2009 Jan;149A(1): 40-60.

56 Hennekam RC, Cormier-Daire V, Hall JG, Méhes K, Patton M, Stevenson RE. Elements of morphology: standard terminology for the nose and philtrum. Am J Med Genet A. 2009 Jan;149A(1):61-76.

57 Carey JC, Cohen MM Jr, Curry CJ, Devriendt $\mathrm{K}$, Holmes LB, Verloes A. Elements of morphology: standard terminology for the lips, mouth, and oral region. Am J Med Genet A. 2009 Jan;149A(1):77-92.

58 Biesecker LG, Aase JM, Clericuzio C, Gurrieri F, Temple IK, Toriello H. Elements of morphology: standard terminology for the hands and feet. Am J Med Genet A. 2009 Jan; 149A(1):93-127.

59 Kanof ME, Lake AM, Bayless TM. Decreased height velocity in children and adolescents before the diagnosis of Crohn's disease. Gastroenterology. 1988 Dec;95(6):1523-7.

60 Sawczenko A, Sandhu BK, Logan RF, Jenkins $\mathrm{H}$, Taylor CJ, Mian S, et al. Prospective survey of childhood inflammatory bowel disease in the British Isles. Lancet. 2001 Apr;357(9262): 1093-4.

61 Cezard JP, Touati G, Alberti C, Hugot JP, Brinon $\mathrm{C}$, Czernichow P. Growth in paediatric Crohn's disease. Horm Res. 2002;58(Suppl 1): 11-5.

62 Timmer A, Behrens R, Buderus S, Findeisen A, Hauer A, Keller KM, et al.; CEDATA-GPGE Study Group. Childhood onset inflammatory bowel disease: predictors of delayed diagnosis from the CEDATA German-language pediatric inflammatory bowel disease registry. J Pediatr. 2011 Mar;158(3):467-473.e2.

63 Karlberg J, Albertsson-Wikland K, Naeraa RW, Rongen-Westerlaken C, Wit JM. Spontaneous growth in girls with Turner's syndrome: Dutch-Swedish-Danish reference values. Acta Paediatr Suppl. 1993;388:126.

64 Sävendahl L, Davenport ML. Delayed diagnoses of Turner's syndrome: proposed guidelines for change. J Pediatr. 2000 Oct;137(4): 455-9.

65 Witt DR, Keena BA, Hall JG, Allanson JE. Growth curves for height in Noonan syndrome. Clin Genet. 1986 Sep;30(3):150-3.

66 Ranke MB. Turner and Noonan syndromes: disease-specific growth and growth-promoting therapies. In Savage MO, Saenger P, Cowell CT, Kelnar CJ, editors. Growth disorders. London: Hodder Arnold; 2007, pp 512-25.

67 Greulich WW, Pyle SJ. Radiographic atlas of skeletal development of the hand and wrist. 2nd ed. California: Stanford University Press; 1959 .
68 Tanner JM, Healy MJR, Goldstein H, Cameron $\mathrm{N}$, editor. Assessment of skeletal maturity and prediction of adult height (TW3 method). 3rd edition. London: W.B. Saunders; 2001.

69 Thodberg HH. Clinical review: an automated method for determination of bone age. J Clin Endocrinol Metab. 2009 Jul;94(7):2239-44.

70 Tatsi C, Gkourogianni A, Mohnike K, DeArment D, Witchel S, Andrade AC, et al. Aggrecan Mutations in Nonfamilial Short Stature and Short Stature Without Accelerated Skeletal Maturation. J Endocr Soc. 2017 Jun;1(8): 1006-11.

71 Hu X, Gui B, Su J, Li H, Li N, Yu T, et al.; Chinese Genetic Short Stature Consortium. Novel pathogenic ACAN variants in non-syndromic short stature patients. Clin Chim Acta. 2017 Jun;469:126-9.

72 Tan TY, Dillon OJ, Stark Z, Schofield D, Alam $\mathrm{K}$, Shrestha R, et al. Diagnostic Impact and Cost-effectiveness of Whole-Exome Sequencing for Ambulant Children With Suspected Monogenic Conditions. JAMA Pediatr. 2017 Sep;171(9):855-62.

73 Donaldson MDC, Paterson W. Abnormal growth: defintion, pathogenesis, and practical assessment. In Kelnar C, Savage M, Saenger P, Cowell C, editor. Growth disorders. London: Edward Arnold Ltd; 2007, p. 185-207.

74 Plotnick LP, et al. Growth, growth hormone and pituitary disorders. In McMillan JA, Feigin $\mathrm{RD}$, DeAngelis $\mathrm{C}$, Jones $\mathrm{MD}$, editor. Oski's Pediatrics Principles \& Practice. Philadelphia, PA: Lippincott Williams \& Wilkins; 2010, p. 2084-88.

75 Patel L, Clayton PE. Investigation of the slowly growing child. In Wass JAH, Stewart PM, Amiel SA, Davies MJ, editor. Oxford Textbook of Endocrinology and Diabetes. Oxford: Oxford University Press; 2011, p. 1065-73.

76 Cohen P, Rogol AD, Deal CL, Saenger P, Reiter EO, Ross JL, et al.; 2007 ISS Consensus Workshop participants. Consensus statement on the diagnosis and treatment of children with idiopathic short stature: a summary of the Growth Hormone Research Society, the Lawson Wilkins Pediatric Endocrine Society, and the European Society for Paediatric Endocrinology Workshop. J Clin Endocrinol Metab. 2008 Nov;93(11):4210-7.

77 Sisley S, Trujillo MV, Khoury J, Backeljauw P. Low incidence of pathology detection and high cost of screening in the evaluation of asymptomatic short children. J Pediatr. 2013 Oct;163(4):1045-51.

78 Evans C, Gregory JW; All Wales Clinical Biochemistry Audit Group. The investigation of short stature: a survey of practice in Wales and suggested practical guidelines. J Clin Pathol. 2004 Feb;57(2):126-30.

79 Grote FK, Oostdijk W, De Muinck KeizerSchrama SM, van Dommelen P, van Buuren S, Dekker FW, et al. The diagnostic work up of growth failure in secondary health care; an evaluation of consensus guidelines. BMC $\mathrm{Pe}$ diatr. 2008 May;8(1):21.
Diagnostic Approach in Children

Referred for Growth Failure
Horm Res Paediatr 2019;91:223-240

DOI: 10.1159/000499915 
80 Scherdel P, Reynaud R, Pietrement C, Salaün JF, Bellaïche M, Arnould M, et al.; EBGM III study group. Priority target conditions for algorithms for monitoring children's growth: interdisciplinary consensus. PLoS One. 2017 Apr;12(4):e0176464.

81 Thomas PW, Singhal A, Hemmings-Kelly M, Serjeant GR. Height and weight reference curves for homozygous sickle cell disease. Arch Dis Child. 2000 Mar;82(3):204-8.

82 De Sanctis V. Growth and puberty and its management in thalassaemia. Horm Res. 2002;58(Suppl 1):72-9.

83 Shalitin S, Carmi D, Weintrob N, Phillip M, Miskin H, Kornreich L, et al. Serum ferritin level as a predictor of impaired growth and puberty in thalassemia major patients. Eur $\mathrm{J}$ Haematol. 2005 Feb;74(2):93-100.

84 Van den Broeck J, Hokken-Koelega A, Wit J. Validity of height velocity as a diagnostic criterion for idiopathic growth hormone deficiency and Turner syndrome. Horm Res. 1999;51(2):68-73.

85 Cianfarani S, Tondinelli T, Spadoni GL, Scirè G, Boemi S, Boscherini B. Height velocity and IGF-I assessment in the diagnosis of childhood onset GH insufficiency: do we still need a second GH stimulation test? Clin Endocrinol (Oxf). 2002 Aug;57(2):161-7.

86 Binder G, Weidenkeller M, Blumenstock G, Langkamp M, Weber K, Franz AR. Rational approach to the diagnosis of severe growth hormone deficiency in the newborn. J Clin Endocrinol Metab. 2010 May;95(5):2219-26.

87 Rosenfeld RG, Albertsson-Wikland K, Cassorla F, Frasier SD, Hasegawa Y, Hintz RL, et al. Diagnostic controversy: the diagnosis of childhood growth hormone deficiency revisited. J Clin Endocrinol Metab. 1995 May; 80(5):1532-40.

88 Hindmarsh PC. Endocrine assessment and principles of endocrine testing. In Savage MO, Saenger P, Cowell CT, Kelnar CJ, editors. Growth disorders. London: Edward Arnold Ltd; 2007, p. 219-229.

89 Darendeliler F, Spinu I, Bas F, Bundak R, Isgüven $\mathrm{P}$, Arslanoğlu I, et al. Reevaluation of growth hormone deficiency during and after growth hormone $(\mathrm{GH})$ treatment: diagnostic value of GH tests and IGF-I and IGFBP-3 measurements. J Pediatr Endocrinol Metab. 2004 Jul;17(7):1007-12.

90 Grimberg A, DiVall SA, Polychronakos C, Allen DB, Cohen LE, Quintos JB, et al.; Drug and Therapeutics Committee and Ethics Committee of the Pediatric Endocrine Society. Guidelines for Growth Hormone and InsulinLike Growth Factor-I Treatment in Children and Adolescents: Growth Hormone Deficiency, Idiopathic Short Stature, and Primary Insulin-Like Growth Factor-I Deficiency. Horm Res Paediatr. 2016;86(6):361-97.

91 Lazar L, Phillip M. Is sex hormone priming in peripubertal children prior to growth hormone stimulation tests still appropriate? Horm Res Paediatr. 2010;73(4):299-302.
92 Lodefalk M, Nilsson O. To Prime or Not to Prime - Is That Still a Question? A Comment on the US Guidelines on Growth Hormone and Insulin-Like Growth Factor-I Treatment in Children and Adolescents. Horm Res Paediatr. 2017;88(2):179-80.

93 Albrecht A, Penger T, Marx M, Hirsch K, Dörr HG. Short-term adverse effects of testosterone used for priming in prepubertal boys before growth hormone stimulation test. J Pediatr Endocrinol Metab. 2018 Jan; 31(1):21-4.

94 Sfeir JG, Kittah NE, Tamhane SU, Jasim S, Chemaitilly W, Cohen LE, et al. Diagnosis of GH Deficiency as a Late Effect of Radiotherapy in Survivors of Childhood Cancers. J Clin Endocrinol Metab. 2018 Aug;103(8): 2785-93.

95 Growth Hormone Research Society; GH Research Society. Consensus guidelines for the diagnosis and treatment of growth hormone (GH) deficiency in childhood and adolescence: summary statement of the GH Research Society. J Clin Endocrinol Metab. 2000 Nov;85(11):3990-3.

96 Blum WF, Alherbish A, Alsagheir A, El Awwa A, Kaplan W, Koledova E, et al. The growth hormone-insulin-like growth factor-I axis in the diagnosis and treatment of growth disorders. Endocr Connect. 2018 Jun;7(6):R212-22.

97 Shen Y, Zhang J, Zhao Y, Yan Y, Liu Y, Cai J. Diagnostic value of serum IGF-1 and IGFBP-3 in growth hormone deficiency: a systematic review with meta-analysis. Eur J Pediatr. 2015 Apr;174(4):419-27.

98 Broeren MA, Krabbe JG, Boesten LS, Hokken-Koelega AC, de Rijke YB. Impact of the Choice of IGF-I Assay and Normative Dataset on the Diagnosis and Treatment of Growth Hormone Deficiency in Children. Horm Res Paediatr. 2018;90(3):181-9.

99 Hawkes CP, Grimberg A. Insulin-Like Growth Factor-I is a Marker for the Nutritional State. Pediatr Endocrinol Rev. 2015 Dec;13(2):499-511.

100 Löfqvist C, Andersson E, Gelander L, Rosberg S, Blum WF, Albertsson Wikland K. Reference values for IGF-I throughout childhood and adolescence: a model that accounts simultaneously for the effect of gender, age, and puberty. J Clin Endocrinol Metab. 2001 Dec;86(12):5870-6.

101 Inoue-Lima TH, Vasques GA, Scalco RC, Nakaguma M, Mendonca BB, Arnhold IJ, et al. IGF-1 assessed by pubertal status has the best positive predictive power for GH deficiency diagnosis in peripubertal children. J Pediatr Endocrinol Metab. 2019 Feb;32(2): 173-9.

102 Hasegawa Y, Hasegawa T, Aso T, Kotoh S, Nose O, Ohyama Y, et al. Clinical utility of insulin-like growth factor binding protein-3 in the evaluation and treatment of short children with suspected growth hormone deficiency. Eur J Endocrinol. 1994 Jul; 131(1):27-32.
103 Rikken B, van Doorn J, Ringeling A, Van den Brande JL, Massa G, Wit JM. Plasma levels of insulin-like growth factor (IGF)-I, IGF-II and IGF-binding protein-3 in the evaluation of childhood growth hormone deficiency. Horm Res. 1998 Sep;50(3):166-76.

104 Cianfarani S, Boemi S, Spagnoli A, Cappa M, Argirò G, Vaccaro F, et al. Is IGF binding protein-3 assessment helpful for the diagnosis of GH deficiency? Clin Endocrinol (Oxf). 1995 Jul;43(1):43-7.

105 Boquete HR, Sobrado PG, Fideleff HL, Sequera AM, Giaccio AV, Suárez MG, et al. Evaluation of diagnostic accuracy of insulin-like growth factor (IGF)-I and IGFbinding protein-3 in growth hormone-deficient children and adults using ROC plot analysis. J Clin Endocrinol Metab. 2003 Oct; 88(10):4702-8.

106 Kayemba-Kay's S, Epstein S, Hindmarsh P, Burguet A, Ingrand P, Hankard R. Does plasma IGF-BP3 measurement contribute to the diagnosis of growth hormone deficiency in children? Ann Endocrinol (Paris). 2011 Jun;72(3):218-23.

107 Jensen RB, Jeppesen KA, Vielwerth S, Michaelsen KF, Main KM, Skakkebaek NE, et al. Insulin-like growth factor I (IGF-I) and IGF-binding protein 3 as diagnostic markers of growth hormone deficiency in infancy. Horm Res. 2005;63(1):15-21.

108 Sizonenko PC, Clayton PE, Cohen P, Hintz RL, Tanaka T, Laron Z. Diagnosis and management of growth hormone deficiency in childhood and adolescence. Part 1: diagnosis of growth hormone deficiency. Growth Horm IGF Res. 2001 Jun;11(3):137-65.

109 Storr HL, Chatterjee S, Metherell LA, Foley C, Rosenfeld RG, Backeljauw PF, et al. Nonclassical growth hormone insensitivity (GHI): characterization of mild abnormalities of GH action. Endocr Rev. 2019 Apr 1; 40(2):476-505.

110 Buckway CK, Guevara-Aguirre J, Pratt KL, Burren CP, Rosenfeld RG. The IGF-I generation test revisited: a marker of $\mathrm{GH}$ sensitivity. J Clin Endocrinol Metab. 2001 Nov; 86(11):5176-83.

111 Selva KA, Buckway CK, Sexton G, Pratt KL, Tjoeng E, Guevara-Aguirre J, et al. Reproducibility in patterns of IGF generation with special reference to idiopathic short stature. Horm Res. 2003;60(5):237-46.

112 Blair JC, Camacho-Hübner C, Miraki Moud F, Rosberg S, Burren C, Lim S, et al. Standard and low-dose IGF-I generation tests and spontaneous growth hormone secretion in children with idiopathic short stature. Clin Endocrinol (Oxf). 2004 Feb;60(2): 163-8.

113 Coutant R, Dörr HG, Gleeson H, Argente J. Diagnosis of endocrine disease: limitations of the IGF1 generation test in children with short stature. Eur J Endocrinol. 2012 Mar; 166(3):351-7. 
114 Walenkamp MJ, Robers JM, Wit JM, Zandwijken GR, van Duyvenvoorde HA, Oostdijk W, et al. Phenotypic features and response to growth hormone treatment of patients with a molecular defect of the IGF-1 receptor. J Clin Endocrinol Metab. 2019 Mar;jc.2018-02065.

115 Dauber A, Muñoz-Calvo MT, Barrios V, Domené HM, Kloverpris S, Serra-Juhé C, et al. Mutations in pregnancy-associated plasma protein $\mathrm{A} 2$ cause short stature due to low IGF-I availability. EMBO Mol Med. 2016 Apr;8(4):363-74.

116 Begemann M, Zirn B, Santen G, Wirthgen E, Soellner L, Buttel HM, et al. Paternally Inherited IGF2 Mutation and Growth Restriction. N Engl J Med. 2015;373(4):349-56.

117 Kempers MJ, Lanting CI, van Heijst AF, van Trotsenburg AS, Wiedijk BM, de Vijlder JJ, et al. Neonatal screening for congenital hypothyroidism based on thyroxine, thyrotropin, and thyroxine-binding globulin measurement: potentials and pitfalls. J Clin Endocrinol Metab. 2006 Sep;91(9):3370-6.

118 Rivkees SA, Bode HH, Crawford JD. Longterm growth in juvenile acquired hypothyroidism: the failure to achieve normal adult stature. N Engl J Med. 1988 Mar;318(10):599-602.

119 Ranke MB, Schwarze CP, Mohnike K, von Mühlendahl KE, Keller E, Willgerodt H, et al. Catch-up growth after childhood-onset substitution in primary hypothyroidism: is it a guide towards optimal growth hormone treatment in idiopathic growth hormone deficiency? Horm Res. 1998;50(5):264-70.

120 Glissen Brown JR, Singh P. Coeliac disease. Paediatr Int Child Health. 2019 Feb;39(1): 23-31.

121 Tümer L, Hasanoglu A, Aybay C. Endomysium antibodies in the diagnosis of celiac disease in short-statured children with no gastrointestinal symptoms. Pediatr Int. $2001 \mathrm{Feb} ; 43(1): 71-3$.

122 Queiroz MS, Nery M, Cançado EL, Gianella-Neto D, Liberman B. Prevalence of celiac disease in Brazilian children of short stature. Braz J Med Biol Res. 2004 Jan;37(1):55-60.

123 van Rijn JC, Grote FK, Oostdijk W, Wit JM. Short stature and the probability of coeliac disease, in the absence of gastrointestinal symptoms. Arch Dis Child. 2004 Sep;89(9):882-3.

124 Bhadada SK, Bhansali A, Kochhar R, Menon AS, Sinha SK, Dutta P, et al. Does every short stature child need screening for celiac disease? J Gastroenterol Hepatol. 2008 Aug; 23(8 Pt 2):e353-6.

125 Bhadada SK, Bhansali A, Ravikumar P, Kochhar R, Nain CK, Dutta P, et al. Changing scenario in aetiological profile of short stature in India-growing importance of celiac disease: a study from tertiary care centre. Indian J Pediatr. 2011 Jan;78(1):41-4.

126 Singh P, Sharma PK, Agnihotri A, Jyotsna VP, Das P, Gupta SD, et al. Coeliac disease in patients with short stature: A tertiary care centre experience. Natl Med J India. 2015 Jul-Aug;28(4):176-80.
127 Stalman SE, Hellinga I, van Dommelen P, Hennekam RC, Saari A, Sankilampi U, et al. Application of the Dutch, Finnish and British Screening Guidelines in a Cohort of Children with Growth Failure. Horm Res Paediatr. 2015;84(6):376-82.

128 Stalman SE, Hellinga I, Wit JM, Hennekam RC, Kamp GA, Plötz FB. Growth failure in adolescents: etiology, the role of pubertal timing and most useful criteria for diagnostic workup. J Pediatr Endocrinol Metab. 2016 Apr;29(4):465-73.

129 Saari A, Harju S, Mäkitie O, Saha MT, Dunkel L, Sankilampi U. Systematic growth monitoring for the early detection of celiac disease in children. JAMA Pediatr. 2015 Mar;169(3):e1525.

130 Kahrs CR, Magnus MC, Stigum H, Lundin KE, Størdal K. Early growth in children with coeliac disease: a cohort study. Arch Dis Child. 2017 Nov;102(11):1037-43.

131 Husby S, Koletzko S, Korponay-Szabó IR, Mearin ML, Phillips A, Shamir R, et al.; ESPGHAN Working Group on Coeliac Disease Diagnosis; ESPGHAN Gastroenterology Committee; European Society for Pediatric Gastroenterology, Hepatology, and Nutrition. European Society for Pediatric Gastroenterology, Hepatology, and Nutrition guidelines for the diagnosis of coeliac disease. J Pediatr Gastroenterol Nutr. 2012 Jan;54(1):136-60.

132 Vriezinga SL, Auricchio R, Bravi E, Castillejo G, Chmielewska A, Crespo Escobar P, et al. Randomized feeding intervention in infants at high risk for celiac disease. N Engl J Med. 2014 Oct;371(14):1304-15.

133 Fine RN. Growth retardation in children with chronic renal insufficiency. Nephron. 1997;76(2):125-9.

134 Nesterova G, Gahl W. Nephropathic cystinosis: late complications of a multisystemic disease. Pediatr Nephrol. 2008 Jun;23(6): 863-78.

135 Greco M, Brugnara M, Zaffanello M, Taranta A, Pastore A, Emma F. Long-term outcome of nephropathic cystinosis: a 20-year single-center experience. Pediatr Nephrol. 2010 Dec;25(12):2459-67.

136 Brodin-Sartorius A, Tête MJ, Niaudet P, Antignac C, Guest G, Ottolenghi C, et al. Cysteamine therapy delays the progression of nephropathic cystinosis in late adolescents and adults. Kidney Int. 2012 Jan;81(2): 179-89.

137 Bertholet-Thomas A, Llanas B, Servais A, Bendelac N, Goizet C, Choukroun G, et al. [Significance of the urine strip test in case of stunted growth]. Arch Pediatr. 2015 Jul; 22(7):756-62.

138 Elmonem MA, Veys KR, Soliman NA, van Dyck M, van den Heuvel LP, Levtchenko E. Cystinosis: a review. Orphanet J Rare Dis. 2016 Apr;11(1):47.

139 Ala-Mello S, Koskimies O, Rapola J, Kääriäinen H. Nephronophthisis in Finland: epidemiology and comparison of ge- netically classified subgroups. Eur J Hum Genet. 1999 Feb-Mar;7(2):205-11.

140 Langeveld M, Hollak CE. Bone health in patients with inborn errors of metabolism. Rev Endocr Metab Disord. 2018 Mar;19(1):8192.

141 Mul D, Grote FK, Goudriaan JR, de Muinck Keizer-Schrama SM, Wit JM, Oostdijk W. Should blood gas analysis be part of the diagnostic workup of short children? Auxological data and blood gas analysis in children with renal tubular acidosis. Horm Res Paediatr. 2010;74(5):351-7.

142 Brain CE, Savage MO. Growth and puberty in chronic inflammatory bowel disease. Baillieres Clin Gastroenterol. 1994 Mar; 8(1):83-100.

143 Sawczenko A, Sandhu BK. Presenting features of inflammatory bowel disease in Great Britain and Ireland. Arch Dis Child. 2003 Nov;88(11):995-1000.

144 Gravholt CH. Clinical practice in Turner syndrome. Nat Clin Pract Endocrinol Metab. 2005 Nov; 1(1):41-52.

145 Gravholt $\mathrm{CH}$, Andersen NH, Conway GS Dekkers OM, Geffner ME, Klein KO, et al.; International Turner Syndrome Consensus Group. Clinical practice guidelines for the care of girls and women with Turner syndrome: proceedings from the 2016 Cincinnati Inter-national Turner Syndrome Meeting. Eur J Endocrinol. 2017 Sep;177(3):G1-70.

146 van Pareren YK, de Muinck Keizer-Schrama SM, Stijnen T, Sas TC, Jansen M, Otten $\mathrm{BJ}$, et al. Final height in girls with turner syndrome after long-term growth hormone treatment in three dosages and low dose estrogens. J Clin Endocrinol Metab. 2003 Mar; 88(3):1119-25.

147 Rosilio M, Huber-Lequesne C, Sapin H, Carel JC, Blum WF, Cormier-Daire V. Genotypes and phenotypes of children with SHOX deficiency in France. J Clin Endocrinol Metab. 2012 Jul;97(7):E1257-65.

148 Grandone A, Del Vecchio Blanco F, Torella A, Caruso M, De Luca F, Di Mase R, et al. Multiplex Ligation-Dependent Probe Amplification Accurately Detects Turner Syndrome in Girls with Short Stature. Horm Res Paediatr. 2016;86(5):330-6.

149 van Buuren S, van Dommelen P, Zandwijken GR, Grote FK, Wit JM, Verkerk PH. Towards evidence based referral criteria for growth monitoring. Arch Dis Child. 2004 Apr;89(4):336-41

150 Saari A, Sankilampi U, Hannila ML, Saha MT, Mäkitie O, Dunkel L. Screening of turner syndrome with novel auxological criteria facilitates early diagnosis. J Clin Endocrinol Metab. 2012 Nov;97(11):E2125-32.

151 Malaquias AC, Scalco RC, Fontenele EG, Costalonga EF, Baldin $\mathrm{AD}, \mathrm{Braz} \mathrm{AF}$, et al. The sitting height/height ratio for age in healthy and short individuals and its potential role in selecting short children for SHOX analysis. Horm Res Paediatr. 2013; 80(6):449-56.
Diagnostic Approach in Children

Referred for Growth Failure
Horm Res Paediatr 2019:91:223-240 
152 Grote FK, van Dommelen P, Oostdijk W, de Muinck Keizer-Schrama SM, Verkerk PH, Wit JM, et al. Developing evidence-based guidelines for referral for short stature. Arch Dis Child. 2008 Mar;93(3):212-7.

153 Christesen HT, Pedersen BT, Pournara E, Petit IO, Júlíusson PB. Short Stature: Comparison of WHO and National Growth Standards/References for Height. PLoS One. 2016 Jun;11(6):e0157277.

154 Scherdel P, Matczak S, Léger J, MartinezVinson C, Goulet O, Brauner R, et al. Algorithms to Define Abnormal Growth in Children: External Validation and Head-ToHead Comparison. J Clin Endocrinol Metab. 2019 Feb;104(2):241-9.

155 Gicquel C, Gaston V, Cabrol S, Le Bouc Y. Assessment of Turner's syndrome by molecular analysis of the X chromosome in growth-retarded girls. J Clin Endocrinol Metab. 1998 May;83(5):1472-6.

156 Moreno-García M, Fernández-Martínez FJ Barreiro Miranda E. Chromosomal anomalies in patients with short stature. Pediatr Int. 2005 Oct; 47(5):546-9.

157 Figueiredo CC, Kochi C, Longui CA, Rocha MN, Richeti F, Evangelista NM, et al. Size of the exon 1-CAG repeats of the androgen receptor gene employed as a molecular marker in the diagnosis of Turner syndrome in girls with short stature. Genet Mol Res. 2008 Jan;7(1):43-9.

158 Eggert P, Pankau R, Oldigs HD. How necessary is a chromosomal analysis in growthretarded girls? Clin Genet. 1990 May;37(5): 351-4.

159 Partsch CJ, Raffenberg U, Sippell WG. Screening for Turner's syndrome by chromosome analysis of all girls with short stature. J Pediatr. 2002 Jan;140(1):140-1.

160 Hagen CP, Main KM, Kjaergaard S, Juul A $\mathrm{FSH}, \mathrm{LH}$, inhibin $\mathrm{B}$ and estradiol levels in Turner syndrome depend on age and karyotype: longitudinal study of 70 Turner girls with or without spontaneous puberty. Hum Reprod. 2010 Dec;25(12):3134-41.

161 Prakash S, Guo D, Maslen CL, Silberbach M, Milewicz D, Bondy CA; GenTAC Investigators. Single-nucleotide polymorphism array genotyping is equivalent to metaphase cytogenetics for diagnosis of Turner syndrome. Genet Med. 2014 Jan;16(1):53-9.
162 Gijsbers AC, Ruivenkamp CA. Molecular karyotyping: from microscope to SNP arrays. Horm Res Paediatr. 2011;76(3):20813.

163 Miller DT, Adam MP, Aradhya S, Biesecker LG, Brothman AR, Carter NP, et al. Consensus statement: chromosomal microarray is a first-tier clinical diagnostic test for individuals with developmental disabilities or congenital anomalies. Am J Hum Genet. 2010 May;86(5):749-64.

164 Flechtner I, Lambot-Juhan K, Teissier R, Colmenares A, Baujat G, Beltrand J, et al. Unexpected high frequency of skeletal dysplasia in idiopathic short stature and small for gestational age patients. Eur J Endocrinol. 2014 Apr;170(5):677-84.

165 Yang Y, Muzny DM, Xia F, Niu Z, Person R, Ding $\mathrm{Y}$, et al. Molecular findings among patients referred for clinical whole-exome sequencing. JAMA. 2014 Nov;312(18):18709

166 Stark Z, Tan TY, Chong B, Brett GR, Yap P, Walsh M, et al.; Melbourne Genomics Health Alliance. A prospective evaluation of whole-exome sequencing as a first-tier molecular test in infants with suspected monogenic disorders. Genet Med. 2016 Nov; 18(11):1090-6.

167 Stark Z, Schofield D, Alam K, Wilson W, Mupfeki N, Macciocca I, et al. Prospective comparison of the cost-effectiveness of clinical whole-exome sequencing with that of usual care overwhelmingly supports early use and reimbursement. Genet Med. 2017 Aug;19(8):867-74

168 Vissers LE, van Nimwegen KJ, Schieving JH, Kamsteeg EJ, Kleefstra T, Yntema HG, et al. A clinical utility study of exome sequencing versus conventional genetic testing in pediatric neurology. Genet Med. 2017 Sep;19(9): 1055-63.

169 Dillon OJ, Lunke S, Stark Z, Yeung A, Thorne N, Gaff C, et al.; Melbourne Genomics Health Alliance. Exome sequencing has higher diagnostic yield compared to simulated disease-specific panels in children with suspected monogenic disorders. Eur J Hum Genet. 2018 May;26(5):644-51.

170 Schouten JP, McElgunn CJ, Waaijer R, Zwijnenburg D, Diepvens F, Pals G. Relative quantification of 40 nucleic acid sequences by multiplex ligation-dependent probe amplification. Nucleic Acids Res. 2002 Jun; 30(12):e57.
171 Donze SH, Meijer CR, Kant SG, Zandwijken GR, van der Hout AH, van Spaendonk RM, et al. The growth response to $\mathrm{GH}$ treatment is greater in patients with SHOX enhancer deletions compared to SHOX defects. Eur J Endocrinol. 2015 Nov; 173(5):611-21.

172 Stalman SE, Solanky N, Ishida M, AlemánCharlet C, Abu-Amero S, Alders M, et al. Genetic Analyses in Small-for-GestationalAge Newborns. J Clin Endocrinol Metab. 2018 Mar;103(3):917-25.

173 Renes JS, Willemsen RH, Wagner A, Finken MJ, Hokken-Koelega AC. Bloom syndrome in short children born small for gestational age: a challenging diagnosis. J Clin Endocrinol Metab. 2013 Oct;98(10):3932-8.

174 de Sanctis L, Vai S, Andreo MR, Romagnolo D, Silvestro L, de Sanctis C. Brachydactyly in 14 genetically characterized pseudohypoparathyroidism type Ia patients. J Clin Endocrinol Metab. 2004 Apr;89(4):1650-5.

175 Linglart A, Salles JP. Hypophosphatasia: the contribution of imaging. Arch Pediatr. 2017;24:5S74-79

176 Fotiadou AN, Calleja M, Hargunani R, Keen R. Skeletal Manifestations of Osteogenesis Imperfecta. Semin Musculoskelet Radiol. 2016 Jul;20(3):279-86.

177 Mazen I, Ismail S, Amr K, El Gammal M, Abdel-Hamid M. Hereditary 1,25-dihydroxyvitamin D-resistant rickets with alopecia in four Egyptian families: report of three novel mutations in the vitamin D receptor gene. J Pediatr Endocrinol Metab. 2014 Sep;27(9-10):873-8.

178 Oestreich AE. Concave distal end of ulna metaphysis alone is not a sign of rickets. Pediatr Radiol. 2015 Jul;45(7):998-1000.

179 Child CJ, Kalifa G, Jones C, Ross JL, Rappold GA, Quigley CA, et al. Radiological Features in Patients with Short Stature Homeobox-Containing (SHOX) Gene Deficiency and Turner Syndrome before and after 2 Years of GH Treatment. Horm Res Paediatr. 2015;84(1):14-25.

180 Auger J, Baptiste A, Benabbad I, Thierry G, Costa JM, Amouyal M, et al. Genotype-Phenotype Relationship in Patients and Relatives with SHOX Region Anomalies in the French Population. Horm Res Paediatr. 2016;86(5):309-18 